\title{
Social Exclusion, Subjective Academic Success, Well-Being, and the Meaning of Trust
}

\author{
Barbara Thies $^{1} \mathbb{\oplus}$, Elke Heise ${ }^{1}$, and Inka Bormann² \\ ${ }^{1}$ Institut für Pädagogische Psychologie, TU Braunschweig, Germany \\ ${ }^{2}$ Arbeitsbereich Allgemeine Erziehungswissenschaft, Freie Universität Berlin, Germany
}

\begin{abstract}
This article uses a person-environment fit perspective to investigate whether and how educational background and general trust are related to fit (or not) with university life as well as to criteria of subjective academic success and well-being. To analyze how students perceive fit with their university, we measured their perception of exclusion and their affective commitment. The sample includes $N=424$ students from two German universities, about half of whom have at least one parent with tertiary education. The results show that especially general trust is related to the subjective criteria of academic success, and that this relationship is mediated by the perception of exclusion, on the one hand, and by the affective commitment, on the other hand. A comparison of the two mediators shows that the perception of exclusion is particularly potent in terms of predicting satisfaction with coping with study demands and general well-being. We discuss the results in terms of their significance to the future diversity management at universities for overcoming social inequality and increasing social inclusion.
\end{abstract}

Keywords: subjective academic success, well-being, perception of exclusion, affective commitment, general trust

Soziale Exklusion, subjektiver Studienerfolg, Wohlbefinden und die Bedeutung von Vertrauen

Zusammenfassung: Vor dem Hintergrund der P-E-Fit-Theorie wird der Einfluss des Bildungshintergrundes und des generellen Vertrauens auf die subjektive Passung (Fit) der Studierenden zu ihrer Universität sowie auf subjektive Studienerfolgskriterien und Wohlbefinden untersucht. Als Indikatoren des Fits (oder Missfits) der Studierenden mit ihrer Universität werden das Exklusionsempfinden und das affektive Commitment betrachtet. Die Stichprobe umfasst $N=424$ Studierende von zwei Universitäten. Die Hälfte der Studierenden stammt aus Familien mit akademischem Hintergrund. Die Ergebnisse zeigen, dass vor allem das generelle Vertrauen mit den subjektiven Studienerfolgskriterien und dem Wohlbefinden zusammenhängt und dieser Zusammenhang durch das Exklusionsempfinden und das affektive Commitment mediiert wird. Ein Vergleich der beiden Mediatoren zeigt, dass das Exklusionsempfinden insbesondere die Zufriedenheit mit der Bewältigung von Studienbelastungen und das Wohlbefinden vorhersagt. Die Ergebnisse werden im Hinblick auf zukünftige Erfordernisse universitären Diversity Managements zur Reduktion sozialer Ungleichheit und erhöhter Inklusion diskutiert.

Schlüsselwörter: Subjektiver Studienerfolg, Wohlbefinden, Exklusionsempfinden, affektives Commitment, generelles Vertrauen

In recent decades, German education policy has succeeded in increasing the number of first-year university students. More than half of school graduates take up tertiary education, and among this cohort are more and more first-generation students (Middendorff et al., 2017). The success of enhancing the ratio of students from this target group has resulted in a growing diversity at universities. However, access is not the same as success. Whereas Bosse (2015) underlines that the success of firstyear students at universities depends on how, among other things, students deal with personal and social challenges, international surveys stress social inequality concerning the access to and success in universities as pivotal to academic achievement. Particularly in Germa- ny, social and educational background affects educational success, in the sense that students whose parents have lower educational qualifications are less likely to obtain a tertiary degree compared to those who have at least one tertiary-educated parent (OECD, 2018). Recently, Heublein et al. (2017) found that $47 \%$ of students who dropped out left the university during their first year; furthermore, these dropouts were significantly more likely to come from families with lower levels of educational attainment. These findings raise questions about how first-generation students, in contrast to traditional students, experience their transition to university life, how they feel (e.g., a sense of belonging or alienation from the university) - in summary, what degree of fit or misfit they 
experience with their university after transition, and how this fit is interrelated with academic success and wellbeing.

\section{Fitting in at the University - A Special Demand on First-Generation Students?}

The transition from school to university is a highly challenging and critical stage in life (Brahm et al., 2014; Briggs et al., 2012; Kendall et al., 2018). Students acquire new knowledge, grow personally, and expand their cultural capital (Lehmann, 2014). These developments may be especially demanding on first-generation students (sometimes called "nontraditional students"), who can feel alienated or even excluded from their academic environment (Reay et al., 2010). As mentioned above, young adults with lower-educated parents are overall less likely to achieve a tertiary degree than those who have at least one tertiary-educated parent (OECD, 2018). If those with a lower educational background enter the university, they sometimes have severe problems adapting successfully. A substantial body of research shows, on the one hand, that the ability of young adults to integrate into the sociocultural environment of a university is decisive for their academic success (Gale \& Parker, 2012; Jenert et al., 2015). On the other hand, scholars argue that universities are middle-class-oriented and show an "institutional habitus" with specific, partially informal rules for organizational and communicational demands (Reay et al., 2001; Thomas, 2002). However, many first-generation students are not as familiar with the specific expectations of universities concerning behavior, communication, and worldviews as their peers from families with higher educational backgrounds (Devlin, 2013). Indeed, success at the university seems to be related to the individual's capability to interact with institutional requirements. While earlier research was based more on either individual or institutional factors to explain students' transition to university life, more recently the interplay of personal and institutional factors during the transition to university is considered (Devlin, 2013). Related to this, Heublein (2014) discusses a lack of fit between individual and institutional demands as responsible for university dropout rates.

\section{Affective Commitment and Social Exclusion under the Perspective of Person-Environment Fit}

The interplay of individual and institutional features is relevant to research on academic success which refers to the approach of person-environment fit (Edwards et al., 1998). The interactionist theory of person-environment fit assumes that the correspondence between personal factors (e.g., skills or needs) and situational factors (e.g., organization-specific requirements) decisively affects outcome variables such as performance and commitment as well as satisfaction and well-being (Edwards et al., 2006; Edwards \& Shipp, 2007). The effects of person-environment fit have been studied in various fields of research, such as job satisfaction (Hagmaier-Göttle \& Abele-Brehm, 2015; Hardin \& Donaldson, 2014), flow (Albrecht \& Thielgen, 2019), job identification (Weiß et al., 2014), affective organizational commitment (Greguras \& Dieffendorff, 2009), well-being (Stiglbauer \& Kovacs, 2018; Suhlmann et al., 2018; van den Bosch et al., 2019), and study satisfaction (Bohndick et al., 2018), which in turn is taken to be a key criterion of study success.

The decisive factor here is less the objective but rather the subjective fit (Bohndick et al., 2018; Cable \& DeRue, 2002), since both the personal variables and the organization-specific requirements affect intraindividual information processing. Following this line of research, it turns out that both subjective discrepancies between students' abilities and study requirements as well as subjective discrepancies between students' needs and study offers are associated with a diminished level of overall study satisfaction (Heise et al., 1997; Spies et al., 1996; Westermann et al., 1998). Furthermore, Heise and Thies (2015) follow a diversityoriented perspective and show that, for first-year students, the diversity management of university teachers regarding their students' cognitive and motivational skills is a significant predictor of student satisfaction. In general, affective commitment and the experience of social exclusion have increasingly become a focus of research interest. As mentioned above, the affective commitment of students to their university is often discussed as a precondition for study satisfaction and thus also for objective academic success. In this sense, Breitsohl et al. (2009) found that affective commitment is negatively correlated with turnover tendencies.

The construct of social exclusion is now also finding its way into psychological research. Especially for impaired groups (e.g., people with mental disorders both inside and outside of educational institutions), mechanisms of inclusion and exclusion are being discussed, partly related to 
cognitive (Syrjämäki \& Hietanen, 2019) or neural (Morese et al., 2019; Stephens et al., 2012) processes. To clarify whether, how, and to what extent exclusion mechanisms (institutional, interactional, and psychological) are interrelated, Bude and Lantermann (2006) developed the socalled precariousness resource model of the perception of exclusion, which is dedicated to the relationship between objective and subjective exclusion and, thus, between precarious living conditions and the perception of exclusion. This approach provides a framework for analyzing social exclusion; it allows a conceptual distinction between structural or objective exclusion and the perception of exclusion as well as a theoretically derived and tested instrument for measuring the perception of exclusion. The authors assume that the interaction of internal and external resources with the situation in which individuals find themselves - or their interpretation of that situation results in a higher or lower perception of exclusion. Although the model primarily addresses the social situation of individuals, it is transferable to the experience of belonging to or being excluded from an institution. Furthermore, there is a strong analogy to the importance of subjective fit in the person-environment fit approaches. Accordingly, Umlauft et al. (2013) reported unstable connections between objective exclusion characteristics and the perception of exclusion for the school context. Overall, empirical testing of the model shows that objective features of precarious life situations are not sufficient to explain the perception of exclusion.

For students, there are hardly any studies that deal directly or indirectly with perceived exclusion based on their social background. According to the few studies available, students with a migrant background seem to have a lower academic achievement rate in Germany (Burkhart et al., 2011). Further, they achieve poorer exam results, take longer to complete their studies, and drop out more often (Morris-Lange, 2017). Altogether, the abovementioned findings reveal that affective commitment and the perception of social exclusion are relevant indicators of fit or misfit with university life. The interplay between, or distinctiveness of, perception of exclusion and affective commitment as predictors of academic success and wellbeing has not yet been systematically investigated. The following section outlines personal factors related to these indicators of fit.

\section{Educational Background and General Trust as Predictors of Subjective Fit}

Reay et al. (2010) showed that commitment is a particular challenge for first-generation students. Similarly, studies underlined (for the USA) that social background affects the extent to which students believe they belong to (or "fit in"; Aries \& Seider, 2005, 2007) their university. Berger and Milem (1999) also stated that differences in social background have an impact on academic socialization and, ultimately, on the commitment to the university. Similarly, Walton and Cohen $(2007,2011)$ showed that nontraditional students often feel alienated from or uncommitted to their university. Janke et al. (2017) examined differences between first-generation and continuing-generation students, arguing that the experience of a first-generation student's misfit can be explained primarily by social identification and, thus, ultimately by the underlying assumptions of the theory of social identity (Tajfel \& Turner, 1986). Membership in an underprivileged and comparatively small group (many academics still have higher educational backgrounds; see also Hauschildt et al., 2015) can lead to feelings of distance or alienation. Referring to their longitudinal study, Janke et al. reported that the social background is reflected in the social identity (the "social self"); this effect does not level off throughout the study. The authors further argued that the educational background is identity-forming and has a stronger influence than the economic background (Ethier \& Deaux, 1994; Thomas \& Azmitia, 2014). They referred to findings that show that the educational background of the parental home has more to do with lifestyle, behavior, and psychological functioning than the economic background (Snibbe \& Markus, 2005; Stephens et al., 2007).

Apart from the substantial body of research considering the role of social and educational background variables for academic success, another line of reasoning reflects on trust as an element of social capital influencing social identity development (Davis, 2014; Petermann, 2013). Scholars discussed trust as a personality trait that is relatively stable (in the sense of Rotter, 1967), or as being a rather malleable attitude that is socially learned and varies according to age, sphere of life, and related experiences (Abdelzadeh \& Lundberg, 2017; Flanagan \& Stout, 2010; Freitag \& Bauer, 2016; Glanville \& Paxton, 2007). Consensually, generalized (or basic) and specific trust are distinguished, with stronger generalized trust making the emergence of specific trust more likely (Schweer \& Thies, 2008). Following Rotter's assumptions, the short scale for measuring interpersonal trust (Beierlein et al., 2012) was established to measure 
generalized interpersonal trust. It uses three items to measure how firm the conviction is that one can trust other people on principle. In the validation studies, the scale is linked to personality traits (such as agreeableness), various aspects of satisfaction, mental and physical health, and educational level. Further, international surveys also suggested that individuals display stronger interpersonal trust, the more they are educated in terms of years of schooling (Borgonovi, 2012; Borgonovi \& Burns, 2015; Charron \& Rothstein, 2016). Under this perspective, trust (or the capability to trust) is unequally distributed.

Regarding students, scholars also supported the assumption of trust being a prerequisite for the use of social capital that may help students to develop educational aspirations (Fuller, 2014), or that trust enables successful interaction and inclusion in new environments (White, 2014). Accordingly, trust can be seen as part of an individual's capital or as a resource. From this angle, Bormann and Thies (2019a) argued that general trust (in the sense of Rotter, 1967, and Beierlein et al., 2012) helps students enter the university and supports them in using formal and informal support structures that might enable their fit with university life. In this line of argumentation, the developing "habitual trust" (as a specific form of trust in academic socialization) leads to current or prospective advantages resulting from affiliation to (and interaction with) certain groups and networks providing resources such as support, access, and information (Bormann \& Thies, 2019a). Because especially first-year students find themselves in an unfamiliar environment, dealing with the complexity resulting from such unfamiliarity may be facilitated by their general trust. In general, trust helps to deal with complexity and uncertainty; it is considered a powerful resource for coping with demanding interpersonal interactions as well as with institutions (Bachmann \& Inkpen, 2007; Frederiksen, 2014; Luhmann, 2000). Greater general trust may be helpful to join others and feel included and, in this sense, fosters the fit with university life.

\section{Subjective Fit as a Predictor of Academic Success and Well-Being}

Academic success is often measured by objective factors such as dropout rates and adherence to standard study periods and, in some cases, final grades (these are, however, viewed particularly critically because of the differences in topic groups and university locations, Wissenschaftsrat, 2012). In contrast, there are more and more studies that understand academic success multidimensionally and distinguish objective and subjective criteria of academic success (Heinze, 2018). Mainly study satisfaction and sometimes drop-out tendencies are considered as subjective criteria of academic success (Biermann et al., 2017; Kesseler et al., 2016). Study satisfaction can be defined as an attitude, analogous to job satisfaction (Felfe \& Six, 2006; Westermann \& Heise, 2018). According to Westermann et al. (1996), study satisfaction can be divided into satisfaction with content, with conditions, and with coping with study demands. Low study satisfaction is related to the intention to drop out of the study program (Werner, 2008). Blüthmann (2012) showed that variables directly related to the learning process (quality of teaching, study climate, own motivation to learn, acquired expertise) show significant correlations with study satisfaction. The assumed relationship between well-being and study satisfaction depends on the constructs and operationalizations used. While some researchers have treated satisfaction as an element of wellbeing (Antaramian, 2017), others distinguished these constructs (Janke et al., 2017).

Related to well-being and life satisfaction, the (mental) health of students has also increasingly come into the focus of scientific and public attention. The reported numbers of (mentally) impaired students fluctuate. A representative survey of German students showed that $3 \%$ of students suffer from mental illness and study difficulties (Middendorff, 2013), while a health insurance company states that $21 \%$ of their insured students have a mental disorder (Techniker Krankenkasse, 2015). Barthel and Rawohl (2008) found that students are not more often mentally ill than the general population (but also not healthier; for a more detailed overview, see Hofmann et al., 2017). The WHO World Mental Health Surveys International College Student Project (Auerbach et al., 2018) reported about one-third of the students screening positively for a mental disorder. Furthermore, empirical results suggested that the experience of ostracism as a special form of being socially excluded negatively influences well-being (Pollatos et al., 2015). In this sense, wellbeing can be regarded as interrelated with the felt fit with university.

\section{Research Questions and Hypotheses}

Relying on the theory of person-environment fit, we assume that perception of exclusion and affective commitment as indicators of fit or misfit with the university 


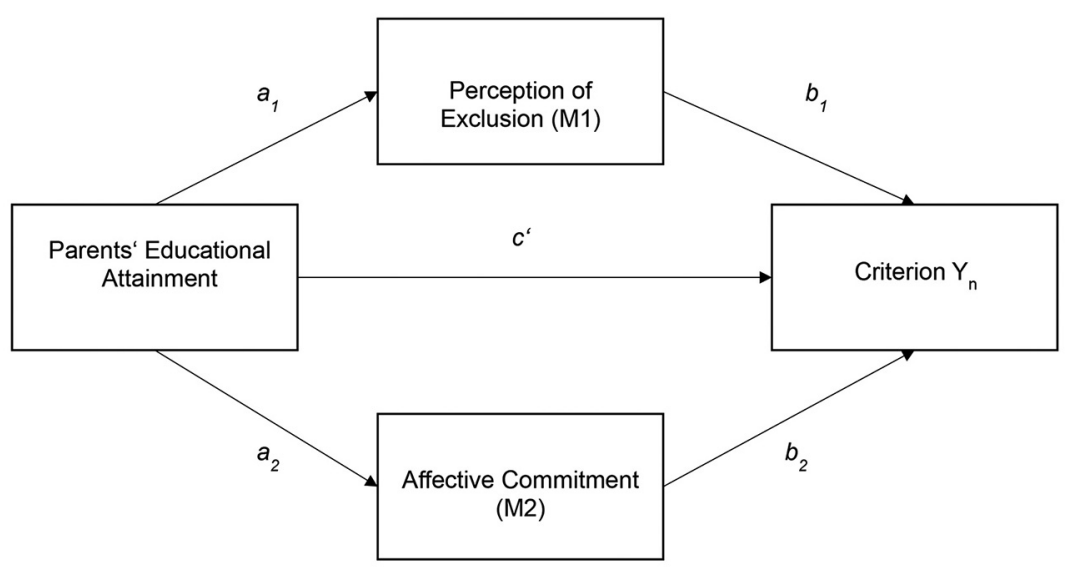

Note. The model is visualized with perception of exclusion and affective commitment as mediators for the effect of parents' educational attainment on academic success criteria and well-being. This model serves as well for parallel multiple regression analyses with perception of exclusion and affective commitment as mediators for the effect of general trust on academic success criteria and well-being.

Figure 1. Statistical model of the parallel multiple mediation analyses. mediate the effect of the personal variables parents' educational attainment and general trust on academic success criteria (study satisfaction and intention to drop out) as well as on well-being. This assumption is visualized in Figure 1.

\section{Hypotheses}

Hypothesis 1 (H1): Perception of exclusion and affective commitment mediate the effect of parents' educational attainment on study satisfaction.

Hypothesis 2 (H2): Perception of exclusion and affective commitment mediate the effect of parents' educational attainment on intention to drop out.

Hypothesis 3 (H3): Perception of exclusion and affective commitment mediate the effect of parents' educational attainment on well-being.

Hypothesis 4 (H4): Perception of exclusion and affective commitment mediate the effect of general trust on study satisfaction.

Hypothesis 5 (H5): Perception of exclusion and affective commitment mediate the effect of general trust on intention to drop out.

Hypothesis 6 (H6): Perception of exclusion and affective commitment mediate the effect of general trust on wellbeing.

\section{Method}

\section{Sample}

The sample consisted of $N=424$ students from two German universities, 277 studying in a bachelor's program (256 of whom were in their first year, 133 in their first semester), 143 studying in a master's program (with two students in other programs; two students did not provide any information on their study program). 242 were students of the humanities and cultural sciences, 47 of economics and social sciences, and 54 of science and engineering. 53 students could not address one of the above-mentioned categories, and 28 did not respond to this item. 108 males, 306 females, and 10 with a diverse sex were included. Their age ranged from younger than $20(N=118)$ to between 21 and 25 years $(N=194)$, between 26 and 30 years $(N=71)$, and older than $30(N=$ $41)$. We made no hypotheses concerning sociodemographics, so that no further data are reported here (except for educational background, reported below). The online survey was conducted in autumn 2019. Students were recruited via course distribution lists. They participated voluntarily and were not paid.

\section{Measures}

To measure the "educational background", we used an 8point scale varying from no educational attainment to possessing a Ph.D. (see Table 1), asking for the highest educational level of at least one parent (those who ticked the values 1 to 5 are considered first-generation students). For further analyses, this variable was dichotomized ( 0 for first-generation students).

For "general trust" we used the general trust scale "KUSIV3" (Beierlein et al., 2012; e. g., "In general, you can 
Table 1. Parents" highest educational attainment

\begin{tabular}{|c|c|c|}
\hline & $N$ & $\%$ \\
\hline First-generation students & 221 & 52.1 \\
\hline No educational attainment & 5 & 1.2 \\
\hline Secondary school certificate (Hauptschulabschluss) & 18 & 4.2 \\
\hline Intermediate maturity level (Mittlere Reife) & 102 & 24.1 \\
\hline Vocational baccalaureate (Fachabitur) & 32 & 7.5 \\
\hline A-Levels (Abitur) & 64 & 15.1 \\
\hline Traditional students & 195 & 46.9 \\
\hline Bachelor & 30 & 7.1 \\
\hline Master & 143 & 33.7 \\
\hline Ph.D. & 22 & 5.2 \\
\hline Missing & 8 & 1.9 \\
\hline
\end{tabular}

Note. German original names in parentheses.

trust people"). To assess the "perception of exclusion", we adapted the scale of Bude and Lantermann (2006) for university concerns (e.g., "I feel like I don't really belong to the university"). Organizational commitment was measured as "affective commitment" with the scale by Kil et al. (2000; e.g., "I'm glad I'm studying at this university"). Both the perception of exclusion and affective commitment are considered as indicators of the perceived fit with the university. To date, the perception of exclusion at universities has been studied only rarely. Since we were not aware of any established scales, and because the items of both (exclusion and commitment) scales have semantic similarities, we first examined the distinguishability of the constructs by principal component analysis. To keep the factors as independent as possible, we ran a Varimax rotation. According to the eigenvalue criterion, two factors (Factor 1: Affective commitment, eigenvalue 4.64, Factor 2: Perception of exclusion, eigenvalue 2.56) resulted and correspond to the original scales. Hence, they were used for analyses.

Subjective academic success is conceptualized in terms of "study satisfaction" and "intention to drop out." Study satisfaction was measured in the tradition of Westermann et al. (1996) with three subscales, namely, satisfaction with the contents, e.g., "I really enjoy what I study"; satisfaction with the study conditions, e.g., "I wish that the study conditions at the university were better"; and satisfaction with the coping with study demands, e.g., "I often feel tired and exhausted by my studies". Intention to drop out was measured with two items from Deuer and Wild (2018), e.g., "I have already thought about giving up my studies". "Well-being" was measured using the scale of the WHO, a well-established screening method (Brähler et al., 2008; e.g., "For the last two weeks, I felt calm and relaxed"). All items could be answered on scales from 0 (does not apply at all) to 10 (applies completely), except for the well-being items, which were measured with a scale from 0 (never) to 5 (always). Means, standard deviations, and Cronbach's alphas are reported in Table 2.

\section{Statistical Approach}

Our main research interest lies in the mediating effect of the fit-variables perception of exclusion and affective commitment on the relationship between personal variables as predictors and subjective academic success and well-being as criteria. Educational background as a sociodemographic variable and general trust as a medium-term stable variable (i.e., formed before entering the university) can be assumed to have a causal effect on the outcome variables, insofar as they temporally precede them. These assumptions are theoretically derivable despite the cross-sectional data collection. This also applies to the assumed mediators affective commitment and perception of exclusion, since they are theoretically conceived as fit variables that predict the outcome variables.

According to Figure 1, direct (c') and indirect $\left(a_{1} b_{1} ; a_{2} b_{2}\right)$ effects are tested. Parallel multiple mediation analyses are calculated according to Preacher and Hayes (2008) and Hayes (2013) using IBM SPSS Statistics 26 and the SPSS add-on module PROCESS 3.4.1. The estimation of indirect effects in a parallel multiple-mediator model with perception of exclusion and affective commitment as potential mediators allows the simultaneous testing of both psychological processes, taking into account the relationship between them. Thus, each of the analyses includes parents' educational attainment or general trust as a predictor, perception of exclusion and affective commitment as parallel mediators, and, depending on the hypothesis, study satisfaction, intention to drop out, or 
well-being as a criterion. Covariates were introduced to control the effects of gender, bachelor vs. master study program, and first-semester status. Significance testing of the indirect effects was conducted using $95 \%$ biascorrected confidence intervals (BC 95\% CI) from 10.000 bootstrap samples.

\section{Results}

Table 2 shows the intercorrelations and scales' reliabilities. Except for intention to drop out $(\alpha=.665)$, the reliabilities of the scales are good ( $\alpha$ from .807 to .911). The level of parents' educational attainment does not correlate significantly with the criteria, but negatively with the mediator affective commitment $(r=-.097, p<$ $.05)$ and with general trust $(r=.166, p<.01)$. Overall, a variety of significant intercorrelations emerges for general trust with the criteria and the mediators: General trust correlates significantly with study satisfaction with content $(r=.183, p<.01)$, with conditions $(r=.117, p<.05)$, with coping with study demands $(r=.196, p<.01)$, and with well-being $(r=.299, p<.01)$, but not with intention to drop out $(r=-.091, n s)$. A further correlation occurs with the second mediator affective commitment $(r=.111, p<$ .05).

The following sections report the results of parallel multiple mediation analyses. We conducted mediation analyses for parents' educational attainment and for general trust as predictors of subjective academic success criteria and well-being. Mediation analyses were repeated with control for gender, bachelor vs. master study program, and first-semester status, because significant correlations of these variables with criteria, mediators, and independent variables were found. Gender correlates with satisfaction with contents $(r=.100, p<.05)$, intention to drop out $(r=-.144, p<.01)$ as well as with perception of exclusion $(r=-.131, p<.01)$ and affective commitment $(r=$ $.120, p<.05)$. Additionally, there is a correlation with parents' educational attainment $(r=-.109, p<.05)$. In sum, female students seem to be more satisfied with the content and more strongly committed to the university as well as less affected by drop-out intentions and perception of exclusion. Remarkably, female students in this study stem from families with lower parents' educational attainment.

Studying in a bachelor vs. a master program is interrelated with satisfaction with content $(r=-.217, p<.01)$, satisfaction with conditions $(r=-.251, p<.01)$ as well as with the mediators (perception of exclusion: $r=-.118, p<$ .05 , affective commitment: $r=-.159, p<.01)$. Firstsemester status is also associated with satisfaction with content $(r=-.147, p<.01)$, satisfaction with conditions $(r=$ 
$-.152, p<.01)$, intention to drop out $(r=.113, p<.05)$, and affective commitment $(r=-.172, p<.01)$. Master students are less satisfied with content and conditions and feel less excluded as well as less committed. Analogously, firstsemester students are more satisfied with content and conditions, feel more committed to their university and are less affected by drop out intentions.

\section{Influence of Parents' Educational Attainment on Subjective Study Success and Well-Being}

Despite the few significant correlations between parents' educational attainment and the fit variables (mediators) as well as the criteria, we used mediation analyses to examine indirect effects, to get a deeper insight into the role of parents' educational attainment and to test hypotheses 1, 2 and 3 (Table 3).

We found no direct effects $\left(c^{\prime}\right)$ of parents' educational attainment on the criteria. Furthermore, parents' educational attainment does not predict the mediator perception of exclusion $\left(a_{1}=-.01, p=.915\right)$, but only affective commitment $\left(a_{2}=-.19, p=.048\right)$. The mediators significantly predict the criteria: They predict study satisfaction with content $\left(b_{1}=-.22, p=.000, b_{2}=.40, p=.000\right)$, with conditions $\left(b_{1}=-.16, p=.000, b_{2}=.39, p=.000\right)$, and with coping with study demands $\left(b_{1}=-.43, \mathrm{p}=.000, b_{2}=.13, p\right.$ $=.003)$. The mediators also predict the intention to drop out $\left(b_{1}=.35, p=.000, b_{2}=-.18, p=.000\right)$ and well-being $\left(b_{1}=-.31, p=.000, b_{2}=.10, p=.024\right)$.

In the subsequent parallel multiple mediation analyses, we found two indirect effects for educational attainment and affective commitment $\left(a_{2} b_{2}\right)$, namely, in predicting study satisfaction with conditions (partially standardized effect: -.07, 95\%-CI[-.15, -.001]) as well as in predicting intention to drop out $(.03,95 \%-\mathrm{CI}[.0002, .08])$. We found no further indirect effects. In sum, Hypotheses 1, 2, and 3 must be rejected.

When we introduced gender, bachelor vs. master study program, and first-semester status as covariates, only slight changes occurred. An additional indirect effect for affective commitment occurs when predicting study satisfaction with content while controlling for bachelor vs. master program (-.07, 95\%-CI[-.14, -.001]). When predicting intention to drop out, the indirect effect of affective commitment is no longer significant if gender or first-semester status is controlled for.

\section{Influence of General Trust on Subjective Study Success and Well-Being}

We found direct effects (c') of general trust on the criterion variables: General trust significantly predicts satisfaction with content $\left(c^{\prime}=.18, p=.000\right)$, satisfaction with conditions $\left(c^{\prime}=.12, p=.011\right)$, satisfaction with coping with study demands $\left(c^{\prime}=.19, p=.000\right)$ as well as wellbeing $\left(c^{\prime}=.30, p=.000\right)$. Intention to drop out is not predicted by general trust $\left(c^{\prime}=-.08, p=.071\right)$, which predicts the mediators perception of exclusion $\left(a_{1}=-.20, p\right.$ $=.000)$ and affective commitment $\left(a_{2}=.11, p=.023\right)$. The mediators predict satisfaction with content $\left(b_{1}=-.20, p=\right.$ $\left..000, b_{2}=.40, p=.000\right)$, satisfaction with conditions $\left(b_{1}=\right.$ $\left.-.15, p=.000, b_{2}=.38, p=.000\right)$, and satisfaction with coping with study demands $\left(b_{1}=-.40, p=.000, b_{2}=.13, p\right.$ $=.003)$ as well as intention to drop out $\left(b_{1}=.36, p=.000\right.$, $\left.b_{2}=-.18, p=.000\right)$ and well-being $\left(b_{1}=-.27, p=.000, b_{2}=\right.$ $.10, p=.030$ ).

The results of the mediation analyses indicate that both perception of exclusion and affective commitment mediate the effect of general trust on the subjective academic success criteria and well-being (Table 4): The relationship between general trust and the three components of study satisfaction is mediated by perception of exclusion $\left(a_{1} b_{1}\right)$ and affective commitment $\left(a_{2} b_{2}\right)$ (Hypothesis 4$)$. The effect of general trust on study satisfaction with content (total effect: .20, 95\%-CI[.10, .31], $p=.000$, direct effect after entering the mediators: .10, $95 \%-\mathrm{CI}[.01, .20], p=$ .021) is partially mediated by perception of exclusion (indirect effect: .04, 95\%-CI[.01, .07]) and affective commitment (indirect effect: .04, 95\%-CI[.002, .08]). The effect of general trust on study satisfaction with conditions (total effect: .15, 95\%-CI[.03, .28], $p=.011$; direct effect of general trust after entering the mediators not significant: .06, $95 \%-\mathrm{CI}[-.05, .17], p=.279])$ is fully mediated by perception of exclusion (indirect effect: .03, $95 \%-\mathrm{CI}[.01, .05]$ and affective commitment (indirect effect: .04, 95\%-CI[.001, .08]). Finally, the effect of general trust on satisfaction with coping with study demands (total effect: .27, 95\%-CI[.14, .40], $p=.000$; direct effect of general trust after entering the mediators: $.13,95 \%-\mathrm{CI}[.02, .25], p=.020$ ) is partially mediated by perception of exclusion (indirect effect: .08, $95 \%$-CI[.04, .12] and affective commitment (indirect effect: .01, 95\%CI[.0003, .03]), too.

As mentioned above, when predicting students' intention to drop out (Hypothesis 5), we found no direct effects (total effect: -.11, 95\%-CI[-.24, .009], $p=.071$, direct effect after entering the mediators: .00, $95 \%-\mathrm{CI}[-.10$, .12], $p=.865)$. However, we found indirect effects for perception of exclusion [-.07, 95\%-CI[-.11, -.03] and affective commitment $(-.02,95 \%-\mathrm{CI}[-.04,-.005])$. Con- 


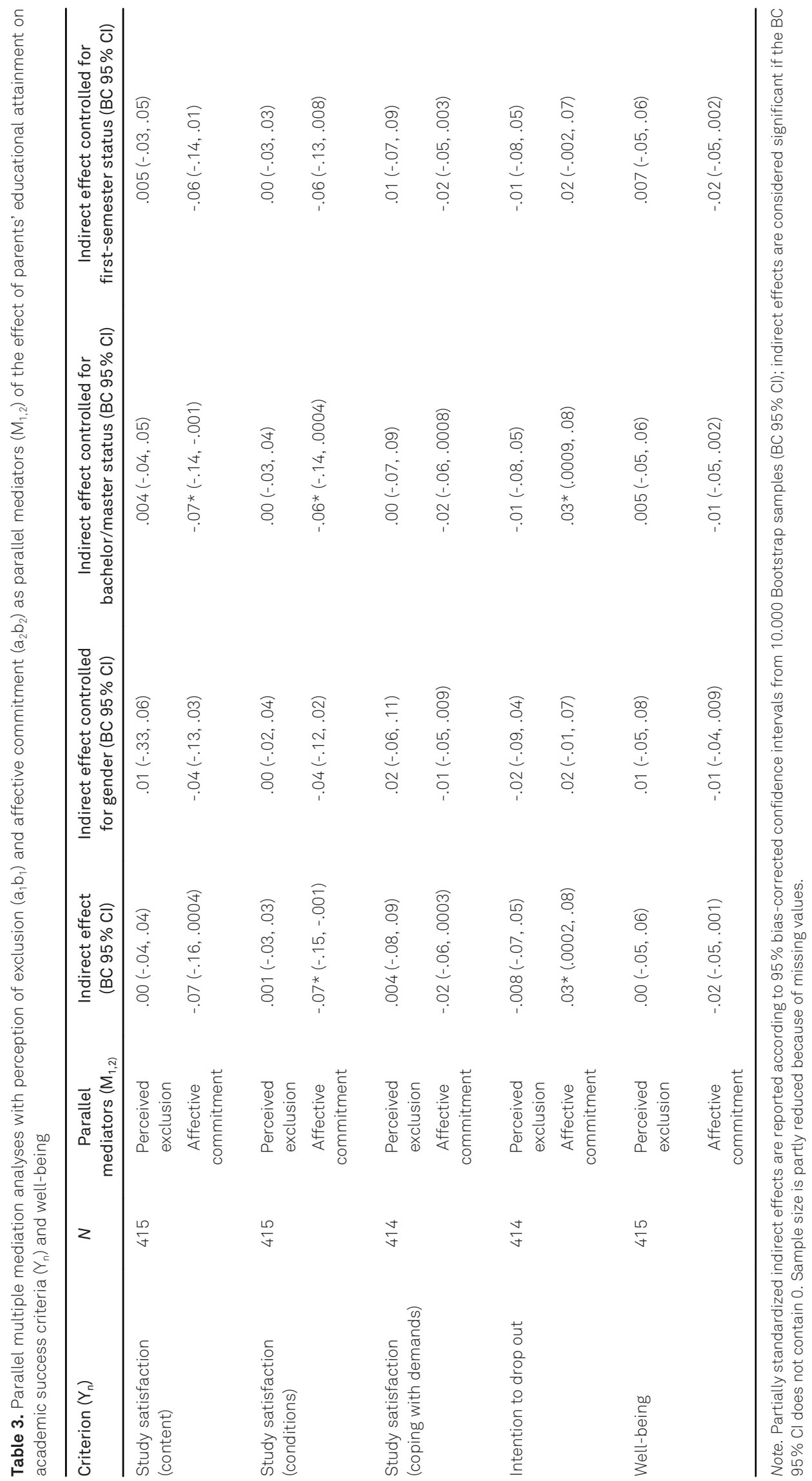




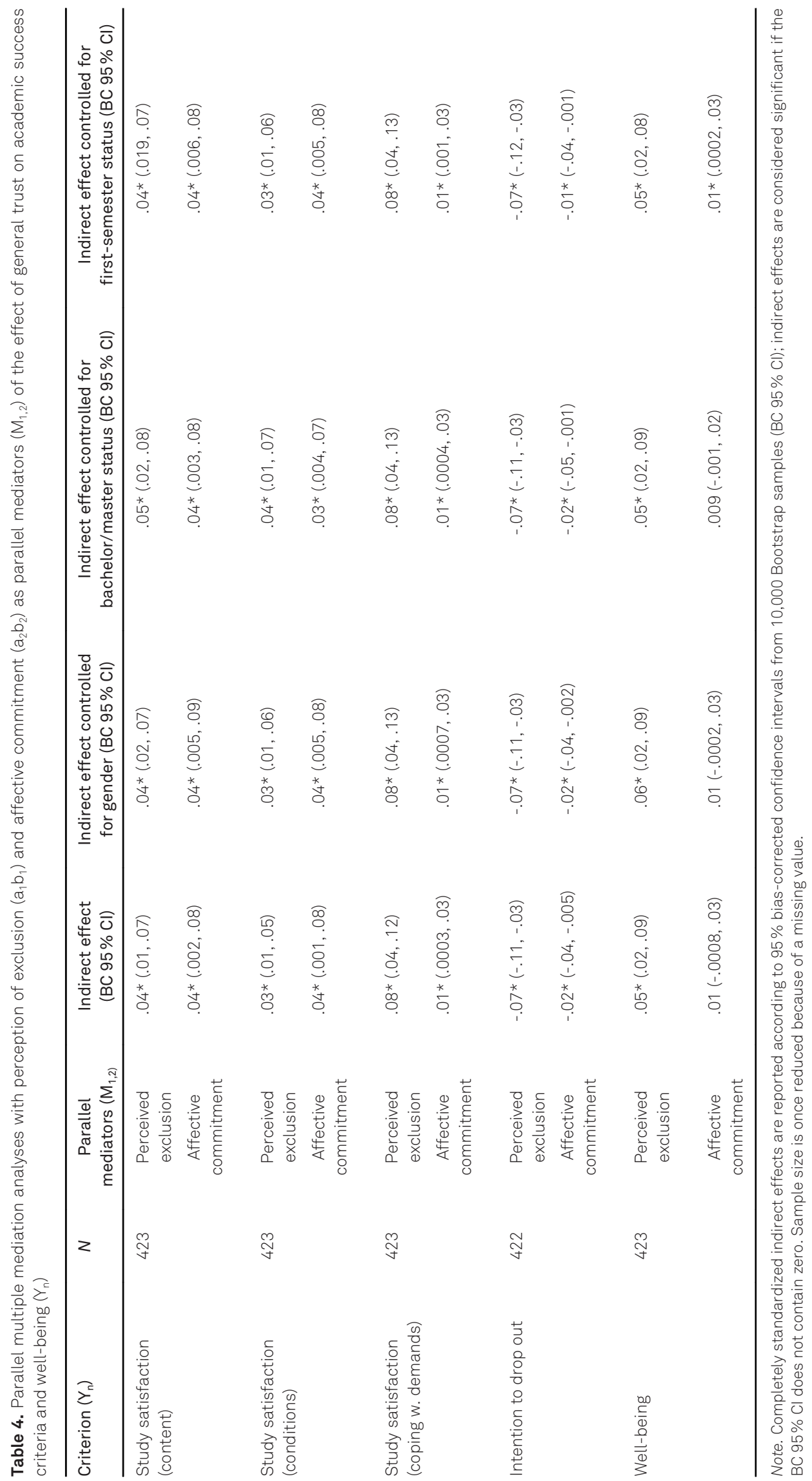


sidering general trust as a predictor of well-being (hypothesis 6), we found a different picture: Only one of the mediators, namely, perception of exclusion, mediated the effect of general trust on the criterion. The relationship between general trust and well-being (total effect: .14, $95 \%$-CI [.10, .19], $p=.000$, direct effect after entering the mediators: .11, 95\%-CI[.07, .15], $p=.000$ ) is partially mediated by perception of exclusion (indirect effect .05, $95 \%-C I[.02, .09])$.

When introducing gender, bachelor vs. master study program, and first-semester status as covariates, we found only slight differences. When the first-semester status is controlled for, we found a significant indirect effect of general trust on well-being through affective commitment (indirect effect: .01, 95\%-CI[.0002, .03].

\section{Summary and Discussion}

The present study investigated the mediating role of academic fit (perceived exclusion and affective commitment) within the relationship between two personal variables, namely, parents' educational attainment and general trust, and university students' subjective academic success and well-being. In accordance with prior findings (e.g., Bormann \& Thies, 2019b; Fuller, 2014; White, 2014), lower general trust is linked with a stronger perception of exclusion (as an indicator of misfit). Furthermore, general trust significantly predicts study satisfaction and well-being.

Contrary to previous expectations, parents' educational attainment hardly corresponds with the students' subjective academic success and is connected only with one of the two fit variables (affective commitment). Higher educational attainment of parents is unexpectedly associated with lower affective commitment to the university (as an indicator of fit). An explanation for this finding could be that students from higher-educated families tend to struggle less with university life, while students from lesseducated families intensify their affective commitment to cope with their perceived misfit with university life. Focusing on adjusting to the given institutional habitus of the university may prevent them from entertaining the perception of being a "fish out of water," as Reay et al. (2010) label it.

As hypothesized, perceived exclusion and affective commitment mediate the effect of students' general trust on academic success criteria. The comparison of the two mediators shows that the perception of exclusion is particularly potent in predicting satisfaction with coping with study demands and general well-being. Students who feel excluded are likely to have difficulties in actively accessing students' networks - they could, however, benefit in terms of mutual support in study progress and sense of belonging (see also Frederiksen, 2012). Further, the mentioned relation between social exclusion, satisfaction and well-being is in line with research on exclusion in other spheres of life (e.g., for patients with psychiatric disorders, see Seidel et al., 2020; or people with intellectual disabilities, see Merrells et al., 2019). As a side effect, we found that general trust is slightly interlinked with educational background. Students from less-educated families seem to enter the university with a lower level of general trust. Previous studies pointed out that lower levels of trust make the transition to and successful integration into university life more difficult (Fuller, 2014; Bormann \& Thies, 2019a). As a result, a misfit with university becomes more likely.

In summary, the findings suggest that students' perception of being excluded from what they think is relevant in the university is particularly critical for their subjective academic success. Appropriate interventions should focus on making a fit with the university more likely by supporting students in increasing and stabilizing their affective commitment to their university to reduce their perception of being excluded. This could be crucial for their well-being and, in the end, their academic success and should be monitored by longitudinal evaluations. Corresponding interventions for students are already available (Marksteiner et al., 2019; Walton \& Cohen, 2011) which focus mainly on awareness of features fostering inclusion and overcoming a feeling of exclusion. The extension and further development of such programs could help students to meet both academic requirements and social challenges in their new environment. However, it should be evaluated in the future whether supplyoriented interventions, such as mentoring programs, or demand-driven interventions, such as individual study counseling, best reach the targeted groups.

Universities as institutions should not focus exclusively on student adaptation but should also change themselves and proactively take into account the growing heterogeneity of their students (Meulemann et al., 2014). This demand is in line with diversity management approaches that value heterogeneity and counteract exclusion phenomena (Linde \& Auferkorte-Michaelis, 2014). Concerning the success of programs to raise the number of firstgeneration students, it is increasingly likely that the university faculty and staff themselves will be more heterogeneous, which in turn will probably slowly lead to universities becoming - in terms of their institutional habituses (e.g., including the manner of speaking and interacting) - even more welcoming and inclusive to firstgeneration students. Another suggestion for intensifying diversity management in universities is to clarify the 
expectation structures of potential students, concerning both course content and university life (Hasenberg \& Schmidt-Atzert, 2013).

\section{Limitations and Future Directions}

This study shows the special role of perception of exclusion and affective commitment for subjective academic success and well-being. However, some limitations deserve attention. First of all, limitations arise because of the nonrepresentative sample. In addition to associated generalization problems, a selection effect may have been present, so that students with a strong perception of exclusion may not have participated in the study, at all. The relatively low mean value on the exclusion scale could be interpreted accordingly. Thus, the systematic analysis of further sociodemographic variables (such as those used as covariates in the present study) would be useful to identify subgroups within the student population based on feature configurations.

The data presented were collected in a cross-sectional study, which is crucial in two respects: First, mediation analyses require causal assumptions. Parents' educational background and general trust are temporally upstream of the mediators and outcome variables, so that causal assumptions in this regard seem to be justified. Concerning the relationships between the mediators and the outcome variables, we must address that, although we followed substantial research directions, different conceptions are at least imaginable. Second, as assumptions about students' transitions and how they experience life at the university have a biographical implication, future research should also use longitudinal data to provide more evidence on how students develop a sense of fit or belonging. In addition to the subjective criteria of academic success, the connection between students' general trust, their perception of exclusion, and their affective commitment with objective academic performance should also be examined.

Last but not least, we have to address the less and unexpected impact of students' educational background (in contrast to large-scale assessments such as those by the OECD mentioned above). Typical measures of educational attainment (like those used here) are probably too broad to understand how students' background influences their biographies. To overcome this, one could go beyond including the parental education status and instead address further spheres of life, which are decisive for life satisfaction and an individual's social integration. For example, students' engagement in social networks as well as lifestyle variables (such as participation in cultural life) could be considered for inclusion. Doing so could provide more specific information about how students are socially embedded and what resources they can benefit from when managing the transition to a new environment.

\section{References}

Abdelzadeh, A., \& Lundberg, E. (2017). Solid or flexible? Social trust from early adolescence to young adulthood. Scandinavian Political Studies, 40(2), 207-227. https://doi.org/10.1111/146 7-9477.12080

Albrecht, J., \& Thielgen, M. (2019). Vom Beruf zur Berufung - die Passung zwischen Arbeit und Berufsinteressen [From profession to vocation - the fit between work and professional interests]. Wirtschaftspsychologie aktuell, 26(3), 38-42.

Antaramian, S. (2017). The importance of the very high life satisfaction for students' academic success. Cogent Education, 4(1), Article 1307622. https://doi.org/10.1080/2331186X.2017. 1307622

Aries, E., \& Seider, M. (2005). The interactive relationship between class identity and the college experience: The case of lower income students. Qualitative Sociology, 28(4), 419-443. https://doi.org/10.1007/s11133-005-8366-1

Aries, E., \& Seider, M. (2007). The role of social class in the formation of identity: A study of public and elite private college students. Journal of Social Psychology, 147(2), 137-157. https://doi.org/10.3200/SOCP.147.2.137-157

Auerbach, R. P., Mortier, P., Bruffaerts, R., Alonso, J., Benjet, C., Cuijpers, P., Demyttenaere, K., Ebert, D. D., Green, J. G., Hasking, P., Murray, E., Nock, M. K., Pinder-Amaker, S., Sampson, N. A., Stein, D. J., Vilagut, G., Zaslavsky, A. M., Kessler, R. C., \& WHO WMH-ICS Collaborators (2018). WHO World Mental Health Surveys International College Student Project: Prevalence and distribution of mental disorders. Journal of Abnormal Psychology, 127(7), 623-638. https://doi.org/ 10.1037/abn0000362

Bachmann, R., \& Inkpen, A. C. (2007). Trust and institutions (Sociological Series, no. 84). Institute for Advanced Studies. https://irihs.ihs.ac.at/id/eprint/1813/

Barthel, Y., \& Rawohl, S. (2008). „Den Studenten geht's doch am besten ..." [The students feel best ...]. In J. Ernst \& H. Götze (Eds.), Sozialmedizinische und gesundheitliche Auswirkungen besonderer Lebensumstände. Leipziger Beiträge zur Sozialmedizin Vol. 2 (pp. 151 -164). Leipziger Universitätsverlag.

Beierlein, C., Kemper, C. J., Kovaleva, A., \& Rammstedt, B. (2012). Kurzskala zur Messung des zwischenmenschlichen Vertrauens: Die Kurzskala Interpersonales Vertrauen (KUSIV3) [Short scale for measuring interpersonal trust: The Interpersonal Trust Short Scale]. http://www.gesis.org/fileadmin/_migrated/con tent_uploads/KUSIV3_Working-paper.pdf

Berger, J. B., \& Milem, J. F. (1999). The role of student involvement and perceptions of integration in a causal model of student persistence. Research in Higher Education, 40(6), 641-664. https://doi.org/10.1023/A:1018708813711

Biermann, A., Kaub, K., Friedrich, A., Wach, F.-S., Ruffing, A., Reichl, C., Hochscheid-Mauel, D., Bedersdorfer, H.W., Spinath, F.M., Karbach, J., \& Brünken, R. (2017). SioS-L - Studie zu individuellen und organisationalen Einflüssen auf den Studienerfolg in der Lehrerbildung [Study of individual and organizational influences on student success in teacher education]. In C. Gräsel \& K. Trempler (Eds.), Entwicklung von Professionalität pädagogischen Personals (pp. 75 -92). SpringerVS. https://doi. org/10.1007/978-3-658-07274-2_5 
Blüthmann, I. (2012). Individuelle und studienbezogene Einflussfaktoren auf die Zufriedenheit von Bachelorstudierenden [Individual and study-related factors influencing the satisfaction of Bachelor students]. Zeitschrift für Erziehungswissenschaft, 15(2), 273 - 303. https://doi.org/10.1007/s11618-012-0270-3

Bohndick, C., Rosmann, T., Kohlmeyer, S., \& Buhl, H. (2018). The interplay between subjective abilities and subjective demands and its relationship with academic success. An application of the person-environment fit theory. Higher Education, 75(5), 839 - 854. https://doi.org/10.1007/s10734-017-0173-6

Borgonovi, F. (2012). The relationship between education and levels of trust and tolerance in Europe. The British Journal of Sociology, 63(1), 146-167. https://doi.org/10.1111/j.14684446.2011.01397.x

Borgonovi, F., \& Burns, T. (2015). The educational roots of trust (OECD Education Working Papers No. 119). OECD Publishing. https://www.oecd-ilibrary.org/education/the-educationalroots-of-trust_5js1kv85dfvd-en

Bormann, I., \& Thies, B. (2019a). Trust and trusting practices during transition to higher education: Introducing a framework of habitual trust. Educational Research, 61(2), 161-180. https://doi.org/10.1080/00131881.2019.1596036

Bormann, I., \& Thies, B. (2019b). Vertrauen als Ressource in der Studieneingangsphase. Eine explorative Mixed-Methods Studie [Trust as a resource in the study entry phase. An explorative mixed-methods study]. In J.-M. Lorenzen, L.-M. Schmidt, \& D. Zifonun (Eds.), Methoden und Methodologien der Bildungsforschung. Quantitative und qualitative Verfahren und ihre Verbindungen (pp. 279 - 301). Beltz Juventa.

Bosse, E. (2015). Exploring the role of student diversity for the first-year experience. Zeitschrift für Hochschulentwicklung, 10(4), 45-66. https://doi.org/10.3217/zfhe-10-04/03

Brähler, E., Mühlan, H., Albani, C., \& Schmidt, S. (2008). Teststatistische Prüfung und Normierung der deutschen Versionen des EUROHIS-QOL Lebensqualität-Index und des WHO-5 Wohlbefindens-Index [Statistical testing and standardization of the German versions of the EUROHIS-QOL Quality of Life Index and the WHO-5 Well-being Index]. Diagnostica, 53(2), 83-96. https://doi.org/10.1026/0012-1924.53.2.83

Brahm, T., Jenert, T., \& Wagner, D. (2014). Nicht für alle gleich: Subjektive Wahrnehmungen des Übergangs Schule - Hochschule [Not the same for everyone: Subjective perceptions of the transition from school to university]. Zeitschrift für Hochschulentwicklung, 9(5), 63 -82. https://doi.org/10.3217/zfhe-905/04

Breitsohl, H., Jakobs, T., Ruhle, S., \& Gries, D. (2009). Ausprägung und Antezendenzfaktoren des Organizational Commitment von Studierenden: Eine Querschnittuntersuchung des Fachbereich B an der Bergischen Universität Wuppertal (Arbeitspapiere des Fachbereichs Wirtschaftswissenschaft, 210) [Characteristics and antecedent factors of the organizational commitment of students: A cross-sectional study of the Department B at the University of Wuppertal (Working papers of the Faculty of Economic Sciences, 210)]. http://elpub.bib.uni-wuppertal.de/ servlets/DocumentServlet?id $=687$

Briggs, A. R. J., Clark, J., \& Hall, I. (2012). Building bridges: Understanding student transition to university. Quality in Higher Education, 18(1), 3-21. https://doi.org/10.1080/13538322. 2011. 614468

Bude, H., \& Lantermann, E.-D. (2006). Soziale Exklusion und Exklusionsempfinden [Social exclusion and perception of exclusion]. Kölner Zeitschrift für Soziologie und Sozialpsychologie, 58(2), 233 - 252. https://doi.org/10.1007/s11575-006-0054-1

Burkhart, S., Heublein, U., \& Wank, J. (2011). Bildungsinländer 2011. Daten und Fakten zur Situation von ausländischen Studierenden mit deutscher Hochschulzugangsberechtigung
[Educational residents 2011: Facts and figures on the situation of foreign students with German university entrance qualifications]. https://www.daad.de/imperia/md/content/presse/bil dungsinlaender_2011_neu.pdf

Cable, D. M., \& DeRue, D. S. (2002). The convergent and discriminant validity of subjective fit perceptions. Journal of Applied Psychology, 87(5), 875-884. https://doi.org/10.1037/00219010. 87.5.875

Charron, N., \& Rothstein, B. (2016). Does education lead to higher generalized trust? The importance of quality of government. International Journal of Educational Development, 50, 59-73. https://doi.org/10.1016/j.ijedudev.2016.05.009

Davis, J. B. (2014). Social capital and social identity: Trust and conflict. In A. Christoforou \& J. B. Davis (Eds.), Social capital and economics: Social values, power, and identity (pp. 98-113). Routledge.

Deuer, E., \& Wild, S. (2018). Validierung eines Instruments zur Erfassung der Studienabbruchneigung bei dual Studierenden [Validation of an instrument for recording the tendency of dual students to drop out]. (Forschungsberichte zur Hochschulforschung). https://www.dhbw.de/studie.html

Devlin, M. (2013). Bridging socio-cultural incongruity: Conceptualising the success of students from low socio-economic status backgrounds in Australian higher education. Studies in Higher Education, 38(6), 939 - 949. https://doi.org/10.1080/03075079. 2011.613991

Edwards, J. R., Caplan, R. D., \& Harrison, R. V. (1998). Personenvironment fit theory: Conceptual foundations, empirical evidence, and directions for future research. In C. L. Cooper (Ed.), Theories of organizational stress (pp. 28-67). Oxford University Press. http://public.kenan-flagler.unc.edu/faculty/ edwardsj/Edwardsetal1998.pdf

Edwards, J. R., Cable, D.M., Williamson, I. O., Schurer Lambert, L., \& Shipp, A. J. (2006). The phenomenology of fit. Linking the person and environment to the subjective experience of personenvironment fit. Journal of Applied Psychology, 91(4), 802 - 827. https://doi.org/10.1037/0021-9010.91.4.802

Edwards, J. R., \& Shipp, A. J. (2007). The relationship between person-environment fit and outcomes: An integrative theoretical framework. In C. Ostroff \& T. A. Judge (Eds.), Perspectives on organizational fit (pp. 209 -258). Lawrence Erlbaum Associates Publishers.

Ethier, K. A., \& Deaux, K. (1994). Negotiating social identity when contexts change: Maintaining identification and responding to threat. Journal of Personality \& Social Psychology, 67(2), $243-$ 251. https://doi.org/10.1037/0022-3514.67.2.243

Felfe, J., \& Six, B. (2006). Die Relation von Arbeitszufriedenheit und Commitment [The relation between job satisfaction and commitment]. In L. Fischer (Ed.), Arbeitszufriedenheit. Konzepte und empirische Befunde (pp. 37 -60). Hogrefe.

Flanagan, C. A., \& Stout, M. (2010). Developmental patterns of social trust between early and late adolescence: Age and school climate effects. Journal of Research on Adolescence, 20(3), 748 - 773. https://doi.org/10.1111/j.1532-7795.2010.006 $58 . x$

Frederiksen, M. (2012). Distrust and mistrust in a high trust environment. In M. Sasaki, \& R. M. Marsh (Eds.), Trust: Comparative perspectives (pp. $99-131$ ). Brill.

Frederiksen, M. (2014). Trust in the face of uncertainty: A qualitative study of intersubjective trust and risk. International Review of Sociology, 24(1), $130-144$. https://doi.org/10.1080/ 03906701.2014 .894335

Freitag, M., \& Bauer, P. C. (2016). Personality traits and the propensity to trust friends and strangers. The Social Science Journal, 53(4), 467 - 476. https://doi.org/10.1016/j.soscij.2015. 12.002 
Fuller, C. (2014). Social capital and the role of trust in aspirations for higher education. Educational Review, 66(2), 131-147. https://doi.org/10.1080/00131911.2013.768956

Gale, T., \& Parker, S. (2012). Navigating change: A typology of student transition in higher education. Studies in Higher Education, 39(5), 734-753. https://doi.org/10.1080/03075079. 2012.721351

Glanville, J. L., \& Paxton, P. (2007). How do we learn to trust? A confirmatory tetrad analysis of the sources of generalized trust. Social Psychology Quarterly, 70(3), 230 - 242. https://doi.org/10. 1177/019027250707000303

Greguras, G. J., \& Diefendorff, J. M. (2009). Different fits satisfy different needs: Linking person-environment fit to employee commitment and performance using self-determination theory. The Journal of Applied Psychology, 94(2), 465 - 477. https://doi. apa.org/doiLanding?doi $=10.1037 \% 2 F a 0014068$

Hagmaier-Göttle, T., \& Abele-Brehm, A. E. (2015). Determinants of job satisfaction: Living one's calling as a neglected predictor? In R. Osbourne (Ed.), Job satisfaction: Determinants, workplace implications and impacts on psychological well-being (pp. $41-$ 58). Nova Science.

Hardin, E. E., \& Donaldson, J. R. (2014). Predicting job satisfaction: A new perspective on person-environment fit. Journal of Counseling Psychology, 61(4), 634-40. https://pubmed.ncbi. nlm.nih.gov/25111704/

Hasenberg, S., \& Schmidt-Atzert, L. (2013). Die Rolle von Erwartungen zu Studienbeginn: Wie bedeutsam sind realistische Erwartungen über Studieninhalte und Studienaufbau für die Studienzufriedenheit? [The role of expectations at the beginning of studying: How important are realistic expectations about study content and study design for study satisfaction?]. Zeitschrift für Pädagogische Psychologie, 27(1-2), 87-93. https://doi.org/10.1024/1010-0652/a000091

Hauschildt, K., Gwosć, C., Netz, N., \& Mishra, S. (2015). Social and economic conditions of student life in Europe: Synopsis of indicators. EUROSTUDENT V 2012-2015. Bertelsmann. https://doi.org/10.3278/6001920bw

Hayes, A. F. (2013). Introduction to mediation, moderation, and conditional process analysis: A regression-based approach. Guilford.

Heinze, D. (2018). Die Bedeutung der Volition für den Studienerfolg. Zu dem Einfluss volitionaler Strategien der Handlungskontrolle auf den Erfolg von Bachelorstudierenden [The importance of volition for academic success: On the influence of volitional strategies of action control on the success of Bachelor students.]. Springer. https://doi.org/10.1007/978-3-658-194031_3

Heise, E., \& Thies, B. (2015). Die Bedeutung von Diversität und Diversitätsmanagement für die Studienzufriedenheit [The importance of diversity and diversity management for study satisfaction]. Zeitschrift für Pädagogische Psychologie, 29(1), 31 - 39. https://doi.org/10.1024/1010-0652/a000143

Heise, E., Westermann, R., Spies, K., \& Schiffler, A. (1997). Studieninteresse und berufliche Orientierungen als Determinanten der Studienzufriedenheit [Study interest and career orientation as determinants of study satisfaction]. Zeitschrift für Pädagogische Psychologie, 11(2), $123-132$.

Heublein, U. (2014). Student drop-out from German higher education institutions. European Journal of Education, 49(4), 497513. https://doi.org/10.1111/ejed.12097

Heublein, U., Ebert, J., Hutzsch, C., Isleib, B., König, R., Richter, J., \& Woisch, A. (2017). Zwischen Studienerwartungen und Studienwirklichkeit [Between study expectations and reality]. Forum Hochschule, DZHW.

Hofmann, F. H., Sperth, M., \& Holm-Hadulla, R. M. (2017). Psychische Belastungen und Probleme Studierender. Entwick- lungen, Beratungs- und Behandlungsmöglichkeiten. [Psychological stress and problems of students. Development, counseling, and treatment]. Psychotherapeut, 62(11), 395-402. https://doi.org/10.1007/s00278-017-0224-6

Janke, S., Rudert, S. C., Marksteiner, T., \& Dickhäuser, O. (2017). Knowing one's place: Parental educational background influences social identification with academia, test anxiety, and satisfaction with studying at university. Frontiers in Psychology, 8, 1326. https://doi.org/10.3389/fpsyg.2017.01326

Jenert, T., Postareff, L., Brahm, T., \& Lindblom-Ylänne, S. (2015). Editorial: Enculturation and development of beginning students. Zeitschrift für Hochschulentwicklung, 10(4), 9-21. https://doi.org/10.3217/zfhe-10-04/01

Kendall, A., Kempson, M., \& French, A. (2018). "How will I know when I'm ready?" Re-imagining FE/HE transitions' as collaborative identity work. Research in Post-Compulsory Education, 23(1), 41-56. https://doi.org/10.1080/13596748.2018.1420 729

Kesseler, C. P. A., Troche, S., \& Zupanic, M. (2016). Zur Konsistenz der Erwartungen an die ideale Persönlichkeit von PsychologieStudierenden und die Auswirkungen auf Studienzufriedenheit und Studienleistung [On the consistency of expectations for the ideal personality of psychology students and the effects on study satisfaction and academic success]. In M. Krämer, S. Preiser \& K. Brusdeylins (Eds.), Psychologiedidaktik und Evaluation XI (pp. 43 -51). Shaker Verlag.

Kil, M., Leffelsend, S., \& Metz-Göckel, H. (2000). Zum Einsatz einer revidierten und erweiterten Fassung des Job Diagnostic Survey im Dienstleistungs- und Verwaltungssektor [Use of a revised and extended version of the Job Diagnostic Survey in service and administration]. Zeitschrift für Arbeits- und Organisationspsychologie, 44(3), 115-128. https://doi.org/10.1026//09324089.44.3.115

Lehmann, W. (2014). Habitus transformation and hidden injuries: Successful working-class university students. Sociology of Education, $\quad 87(1), \quad 1-15 . \quad$ https://doi.org/10.1177/ 0038040713498777

Linde, F., \& Auferkorte-Michaelis, N. (2014). Diversitätsgerecht Lehren und Lernen [Diversity-friendly teaching and learning]. In K. Hansen (Ed.), CSR und Diversity Management (pp. 137 -175). Springer. https://doi.org/10.1007/978-3-642-55233-5_6

Luhmann, N. (2000). Familiarity, confidence, trust: Problems and alternatives. In D. Gambetta (Ed.), Trust: Making and breaking cooperative relations (pp. 94-107). University of Oxford, Department of Sociology. https://www.sociology.ox.ac.uk/papers/ luhmann94-107.pdf

Marksteiner, T., Janke, S., \& Dickhäuser, O. (2019). Effects of a brief psychological intervention on students' sense of belonging and educational outcomes: The role of students' migration and educational background. Journal of School Psychology, 75, 41 - 57. https://doi.org/10.1016/j.jsp.2019.06.002

Merrells, J., Buchanan, A., \& Waters, R. (2019). "We feel left out": Experiences of social inclusion from the perspective of young adults with intellectual disability. Journal of Intellectual \& Developmental Disability, 44(6), 13-22. https://doi.org/10. 3109/13668250.2017.1310822

Meulemann, A. M., Garrett, R., Wrench, A., \& King, S. (2014). "Some people might say l'm thriving but ...": Non-traditional students' experiences of university. International Journal of Inclusive Education, 19(5), 503-517. https://doi.org/10.1080/13603116. 2014.945973

Middendorff, E. (2013). Die wirtschaftliche und soziale Lage der Studierenden in Deutschland 2012. 20. Sozialerhebung des Deutschen Studentenwerks durchgeführt durch das HIS-Institut für Hochschulforschung [The economic and social situation of students in Germany 2012: 20th Social Survey of the German 
Student Union conducted by the HIS Institute for Higher Education Research]. Bundesministerium für Bildung und Forschung (BMBF). https://www.studentenwerke.de/sites/de fault/files/01_20-SE-Hauptbericht.pdf

Middendorff, E., Apolinarski, B., Becker, K., Bornkessel, P., Brandt, T., Heißenberg, S., \& Poskowsky, J. (2017). Die wirtschaftliche und soziale Lage der Studierenden in Deutschland 2016. Zusammenfassung zur 21. Sozialerhebung des Deutschen Studentenwerks - Durchgeführt vom Deutschen Zentrum für Hochschul- und Wissenschaftsforschung [The economic and social situation of students in Germany 2016: Summary of the 21st Social Survey of the Deutsches Studentenwerk - Conducted by the German Centre for Research on Higher Education and Science]. Bundesministerium für Bildung und Forschung (BMBF). https://www.bmbf.de/upload_filestore/pub/Auslaendi sche_Studierende_in_Deutschland_2016.pdf

Morese, R., Lamm, C., Bosco, F. M., Valentini, M. C., \& Silani, G. (2019). Social support modulates the neural correlates underlying social exclusion. Social Cognitive and Affective Neuroscience, 14(6), 633 -643. https://doi.org/10.1093/scan/nsz033

Morris-Lange, S. (2017). Allein durch den Hochschuldschungel. Hürden zum Studienerfolg für internationale Studierende und Studierende mit Migrationshintergrund. Sachverständigenrat deutscher Stiftungen für Integration und Migration GmbH (SVR) [Alone in the college jungle: Barriers to academic success for international students and students with migration background. Expert Council of German Foundations for Integration and Migration $\mathrm{GmbH}$ (SVR)]. https://www.stiftung-mercator. de/media/downloads/3_Publikationen/2017/Mai/

SVR_FB_Hochschuldschungel.pdf

OECD (2018). Education at a Glance 2018: OECD Indicators Country Note: Germany. OECD Publishing. http://gpseducation.oecd. org/Content/EAGCountryNotes/DEU.pdf

Petermann, F. (2013). Psychologie des Vertrauens [Psychology of trust] (4th ed.). Hogrefe.

Pollatos, O., Matthias, E., \& Keller, J. (2015). When interoception helps to overcome negative feelings caused by social exclusion. Frontiers in Psychology, 6, 786. https://doi.org/10.3389/fpsyg. 2015.00786

Preacher, K. J., \& Hayes, A. F. (2008). Asymptotic and resampling strategies for assessing and comparing indirect effects in multiple mediator models. Behavior Research Methods, 40(3), 879-891. https://doi.org/10.3758/BRM.40.3.879

Reay, D., Crozier, G., \& Clayton, J. (2010). "Fitting in" or "standing out": Working-class students in UK Higher Education. British Educational Research Journal, 36(1), 107 -124. https://doi.org/ 10.1080/01411920902878925

Reay, D., David, M., \& Ball, S. (2001). Making a difference? Institutional habituses and higher education choice. Sociological Research Online, 5(4), 14-25. https://doi.org/10.5153/ sro. 548

Rotter, J. B. (1967). A new scale for the measurement of interpersonal trust. Journal of Personality, 35(4), 651-665. https:// doi.org/10.1111/j.1467-6494.1967.tb01454

Schweer, M., \& Thies, B. (2008). Vertrauen [Trust]. In A. E. Auhagen (Ed.), Positive Psychologie. Anleitung zum "besseren" Leben (pp. 136 -149). Beltz Psychologie Verlags Union.

Seidel, E., Padberg, F., Bauriedl-Schmidt, C., Albert, A., Daltrozzo, T., Hall, J., Renneberg, B., Seidl, O., \& Jobst, A. (2020). Response to ostracism in patients with chronic depression, episodic depression and borderline personality disorder a study using Cyberball. Journal of Affective Disorders, 260, 254-262. https://doi.org/10.1016/j.jad.2019.09.021

Snibbe, A. C., \& Markus, H. R. (2005). You can't always get what you want: Educational attainment, agency, and choice. Journal of
Personality \& Social Psychology, 88(4), 703-720. https://doi. org/10.1037/0022-3514.88.4.703

Spies, K., Westermann, R., Heise, E., \& Schiffler, A. (1996). Diskrepanzen zwischen Bedürfnissen und Angeboten im Studium und ihre Beziehungen zur Studienzufriedenheit [Discrepancies between study needs and offerings and their relationships to study satisfaction]. Empirische Pädagogik, 10(4), 377 409.

Stephens, N. M., Markus, H. R., \& Townsend, S. S. (2007). Choice as an act of meaning: The case of social class. Journal of Personality \& Social Psychology, 93(5), 814-830. https://doi. org/10.1037/0022-3514.93.5.814

Stephens, N. M., Townsend, S. S., Markus, H. R., \& Phillips, L. T. (2012). A cultural mismatch: Independent cultural norms produce greater increases in cortisol and more negative emotions among first-generation college students. Journal of Experimental Social Psychology, 48, 1389-1393. https://doi. org/10.1016/j.jesp.2012.07.008

Stiglbauer, B., \& Kovacs, C. (2018). The more, the better? Curvilinear effects of job autonomy on well-being from vitamin model and PE-fit theory perspectives. Journal of Occupational Health Psychology, 23(4), 520-536. https://doi.apa.org/doi Landing?doi=10.1037\%2Focp0000107

Suhlmann, M., Sassenberg, K., Nagengast, B., \& Trautwein, U. (2018). Belonging mediates effects of student-university fit on well-being, motivation, and drop-out intention. Social Psychology, 49(1), 16-28. https://doi.org/10.1027/1864-9335/a00 0325

Syrjämäki, A. H., \& Hietanen, J. K. (2019). The effects of social exclusion on processing of social information - A cognitive psychology perspective. British Journal of Social Psychology, 58(3), 730 - 748. https://doi.org/10.1111/bjso.12299

Tajfel, H., \& Turner, J. C. (1986). The social identity theory of intergroup behaviour. In S. Worchel \& W. G. Austin (Eds.), Psychology of intergroup relations (pp. 7-24). Nelson-Hall. https://doi.org/10.4324/9780203505984-16

Techniker Krankenkasse. (2015). Gesundheitsreport 2015. Gesundheit von Studierenden [Health Report 2015: Students“ health]. https://www.tk.de/tk/broschuerenund-mehr/studienund-auswertungen/gesundheitsreport-2015/718618

Thomas, L. (2002). Student retention in higher education: The role of institutional habitus. Journal of Education Policy, 17(4), 423 442. https://doi.org/10.1080/02680930210140257

Thomas, V., \& Azmitia, M. (2014). Does class matter? The centrality and meaning of social class identity in emerging adulthood. Identity, 14(3), 195-213. https://doi.org/10.1080/15283488. 2014.921171

Umlauft, S., Dalbert, C., \& Schröpper, S. (2013). Die Bedeutung des Gerechtigkeitserlebens für das Exklusionsempfinden [The importance of experienced justice for the perception of exclusion]. In C. Dalbert (Ed.), Gerechtigkeit in der Schule (pp. 109-125). Springer VS. https://doi.org/10.1007/978-3-531-93128-9_6

van den Bosch, R., Taris, T. W., Schaufeli, W. B., Peeters, M. C. W., \& Reijseger, G. (2019). Authenticity at work: A matter of fit? The Journal of Psychology, 153(2), 247-266. https:// doi.org/10. 1080/00223980.2018.1516185

Walton, G. M., \& Cohen, G. L. (2007). A question of belonging: Race, social fit, and achievement. Journal of Personality \& Social Psychology, 92(1), 82-96. https://doi.org/10.1037/0022-3514. 92.1.82

Walton, G. M., \& Cohen, G. L. (2011). A brief social-belonging intervention improves academic and health outcomes of minority students. Science, 331, 1447-1451. https://doi.org/10. 1126/science.1198364

Weiß, S., Krumscheid, M., \& Frieg, P. (2014). Survival of the fittest!? Befunde zum Person-Job-Fit im deutschsprachigen Raum [Sur- 
vival of the fittest!? Findings on person-job-fit in Germanspeaking countries]. Bochum, Fakultät für Psychologie. https:// www.researchgate.net/publication/296701625_Survival_of_ the_fittest_Befunde_zum_Person-Job-Fit_im_deutschsprachi gen_Raum

Werner, G. (2008). Individuelle und institutionelle Faktoren der Bereitschaft zum Studienabbruch - eine Mehrebenenanalyse mit Daten des Konstanzer Studierendensurveys [Individual and institutional factors of intention to drop out - A multi-level analysis with data from the Konstanz Student Survey]. Zeitschrift für Soziologie der Erziehung und Sozialisation, 28(2), $191-206$.

Westermann, R., \& Heise, E. (2018). Studienzufriedenheit [Study satisfaction]. In D. H. Rost, J. R. Sparfeldt \& S. R. Buch (Eds.), Handwörterbuch Pädagogische Psychologie (5th ed., pp. $818-$ 825). Beltz.

Westermann, R., Heise, E., Spies, K., \& Trautwein, U. (1996). Identifikation und Erfassung von Komponenten der Studienzufriedenheit [Identification and Measurement of components of study satisfaction]. Psychologie in Erziehung und Unterricht, 43(1), $1-22$.

White, C. (2014). Using principles of trust to engage support with students from low socioeconomic backgrounds: A practice report. International Journal of the First Year in Higher Education, 5(2), 81 - 87. https://doi.org/10.5204/intjfyhe.v5i2.243
Wissenschaftsrat. (2012). Prüfungsnoten an Hochschulen im Prüfungsjahr 2010. Arbeitsbericht mit einem Wissenschaftspolitischen Kommentar des Wissenschaftsrates [Exam levels at universities in the examination year 2010. Work report commented by the Science Council]. https://www.wissenschafts rat.de/download/archiv/2627-12.pdf?__blob=publicationFi le\&v $=4$

\section{Funding}

Open access publication enabled by TU Braunschweig.

\section{ORCID}

Barbara Thies

(iD) https://orcid.org/0000-0002-3670-3555

Inka Bormann

(iD) https://orcid.org/0000-0002-9372-7334

\section{Barbara Thies}

Institut für Pädagogische Psychologie

TU Braunschweig

Bienroder Weg 82

38106 Braunschweig

barbara.thies@tu-bs.de 